\title{
Early development in the annual fish Cynolebias viarius
}

\author{
M. J. Arezo*, L. Pereiro and N. Berois \\ Biología Celular, Facultad de Ciencias, Universidad de la República, Iguá 4225, \\ Montevideo (11400), Uruguay
}

(Received 31 March 2003, Accepted 21 December 2004)

\begin{abstract}
The detailed characteristics and timing of early development in Cynolebias viarius, an annual fish endemic to Uruguay, were obtained from in vivo observations of embryos cultured under standardized laboratory conditions. The chorion ultrastructure is reported for this species for the first time. Comparison with previous data from other annual fishes showed that $C$. viarius exhibited the longest early development including cleavage, blastula formation and epiboly.

(C) 2005 The Fisheries Society of the British Isles
\end{abstract}

Key words: annual fishes; Cynolebias; developmental stages.

\section{INTRODUCTION}

Fishes have a basal position in the vertebrate lineage and their embryos share general chordate characters with other vertebrates. In addition, most fish embryos develop externally from transparent eggs. These characteristics made them a special model for the study of vertebrate embryogenesis (Langeland \& Kimmel, 1997).

The zebrafish Danio rerio (Hamilton) has become a widely used model organism because its general developmental pattern is similar to all osteichthyans (Metscher \& Ahlberg, 1999). Thus, its embryological development is considered representative for teleosts (Westerfield, 2000).

In annual fishes (order Cyprinodontiformes) a different developmental pattern occurs (Myers, 1952). Between cleavage and embryogenesis, the blastomeres undergo dispersion followed by an aggregation phase. Furthermore, the embryos show reversible arrests (diapauses) at different stages (Wourms, $1972 a, b, c$; Ballard, 1981). This developmental strategy is closely related with their life cycle. These fishes inhabit temporary pools that undergo drying during summer when adults die. The embryos remain buried in the bottom mud and are resistant to desiccation. In the subsequent rainy season, they hatch a few hours after the pool is flooded and a new reproductive cycle begins (Wourms, 1964, 1967, 1972c).

\footnotetext{
*Author to whom correspondence should be addressed. Tel.: +598 $25258618 / 145$; fax: +59825258617 ; email: maui@fcien.edu.uy
} 
The genus Cynolebias occurs from north-eastern Brazil to north-eastern and southern Argentina, Uruguay and Paraguay (Costa, 1995). The more relevant available data on Cynolebias include: ecology and ethology (Vaz Ferreira et al., 1964; Vaz Ferreira \& Sierra, 1973), morphology (Loureiro \& de Sá, 1996, 1998), systematic and phylogeny (Costa, 1995, 1996, 1998) and cytogenetic and molecular phylogeny (Máspoli \& García, 1988; García et al., 1993, 1995, 2000, 2001, 2002). Developmental studies, including cell behaviour during early development, were reported for three species: Cynolebias constanciae Myers, Cynolebias whitei Myers and Cynolebias nigripinnis Regan (Wourms, 1972b; Carter \& Wourms, 1990, 1991). Since this genus is very specious, more data are needed to perform comparative studies.

Cynolebias viarius Vaz-Ferreira, Sierra de Soriano \& Scaglia de Paulete is an endemic species from Uruguay (Vaz Ferreira et al., 1964) and the adults easily adapt to and reproduce in laboratory conditions. Moreover, in spite of this genus being the subject of systematic controversy (Costa, 1998; García et al., 2000,2002 ) members of this species are taxonomically well characterized. These features make it a useful model to study early development.

Interpretation of experimental studies requires the structural and temporal framework provided by morphology and duration of developmental stages (Long \& Ballard, 2001). Thus, as an essential first step, the morphological characteristics and timing of $C$. viarius's early development in standardized laboratory conditions were determined.

\section{MATERIALS AND METHODS}

Adult females and males of $C$. viarius were collected during the rainy season in temporary ponds from Depto Rocha, Uruguay (Fig. 1). They were kept in the laboratory

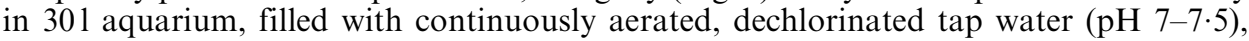
and exposed to natural light for $c .14 \mathrm{~h}$ daily. Mean water temperature was $c .19^{\circ} \mathrm{C}$, and water was partially changed every 5 days. Specimens were fed once a day with live

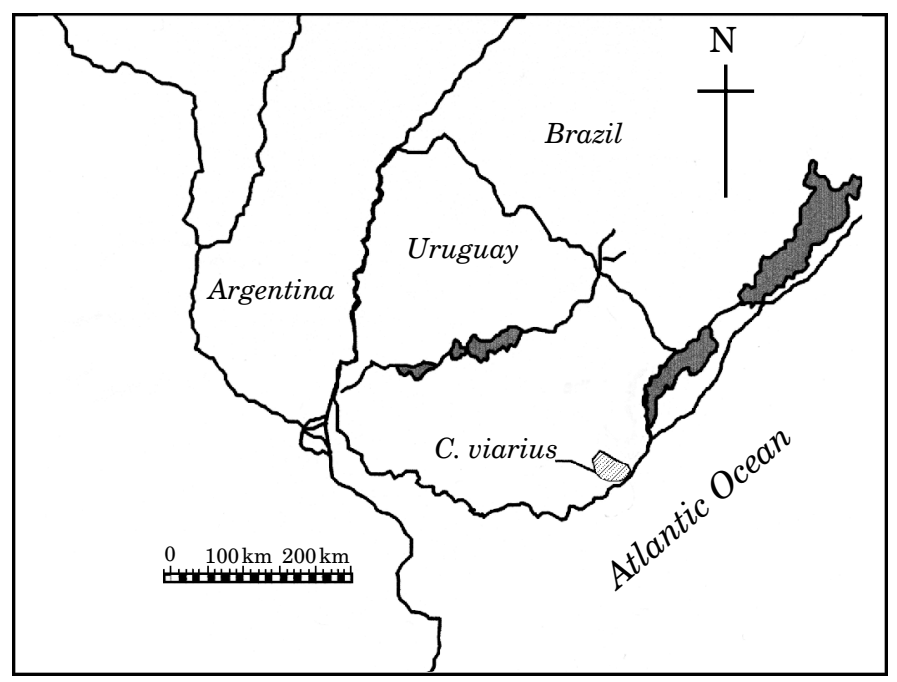

FIG. 1. Map of Uruguay showing Cynolebias viarius collection area ( $\square$ ). 
Tubifex sp. (bloodworms). Spawning was obtained naturally from fish pairs or groups of one male to two females isolated in an aquarium that had a container with peat moss on the bottom. Eggs were collected with a pipette and they were cleaned by rolling with a soft paintbrush on filter paper moistened with aquarium water.

\section{EMBRYO CULTURE}

A total of 1344 fertilized eggs from 30 matings were collected. Eggs were placed in Nunclon 24 well plates ( $1 \mathrm{ml}$ per well working volume) and incubated in darkness at $25^{\circ} \mathrm{C}$ in Yamamoto's solution $\left(\mathrm{NaCl}, 0.75 \%, \mathrm{KCl}, 0.02 \%, \mathrm{CaCl}_{2}, 0.02 \%\right.$; Yamamoto, 1967) plus $100 \mathrm{U} \mathrm{ml}^{-1}$ penicillin $\mathrm{G}$ (Sigma) following Wourms (1972a). Embryos were checked daily by placing each egg, with a drop of Yamamoto solution, in a $1.7 \mathrm{~mm}$ deepchamber carved in tape layers over a microscopic slide. A coverglass, gently placed over the chamber, touched the top of the egg allowing rotation and observation under a light microscope. Live embryos were examined and photographed using an Olympus Vanox microscope.

\section{ULTRASTRUCTURAL ANALYSIS}

Ripe oocytes obtained from ovaries were fixed in $2.5 \%$ glutaraldehyde $/ 0 \cdot 1 \mathrm{M}$ phosphate buffer, $\mathrm{pH} 7.4$, for $2 \mathrm{~h}$. After fixation the oocytes were washed three times $(15 \mathrm{~min}$ each) in $0 \cdot 1 \mathrm{M}$ phosphate buffer and dehydrated in increasing concentrations of acetone (15 to $100 \%$ ). Subsequently, they were dried at the critical point of $\mathrm{CO}_{2}$, mounted on holders and sputtered with gold in a Denton Vacuum LLC Desk II Cold/ETCH UNI sputter apparatus. Specimens were examined and photographed with a JEOL JMS 59000 LV scanning electron microscope (SEM).

\section{RESULTS}

Cynolebias viarius embryos were successfully cultured in Yamamoto's solution. In these conditions it was possible to follow the stages in a large mass of embryos with a good survival rate. It was possible to maintain live embryos without any mould contamination even if dead embryos were present in the same well.

Developmental stages are described below, and the corresponding timing is summarized in Table I.

\section{DEVELOPMENTAL STAGES}

\section{Oocyte}

The oocyte is a hyaline sphere $c .1 .7 \mathrm{~mm}$ in diameter surrounded by a thick acellular chorion. Analysis by SEM reveals the chorion has a rough outer surface ornamented by dense hairlike projections [Fig.2(a)]. Two kinds of hair-like filaments, that differ in thickness, are found. Thick filaments, that appear more rigid, are $2-2 \cdot 3 \mu \mathrm{m}$ in diameter at their base, whereas thinner and more flexible filaments are $0 \cdot 7-1 \cdot 2 \mu \mathrm{m}$ in diameter. Both filaments have an overall cone-shaped morphology. The micropyle, the single site of sperm entry, marks the animal pole [Fig. 2(b)]. The micropyle apparatus does not show any special features. It is a funnel-shaped structure with an external aperture of $c .3 .6 \mu \mathrm{m}$ and the nucleus of the oocyte lies immediately below the micropyle (unpubl. obs.). The yolk is homogeneous in appearance except for 


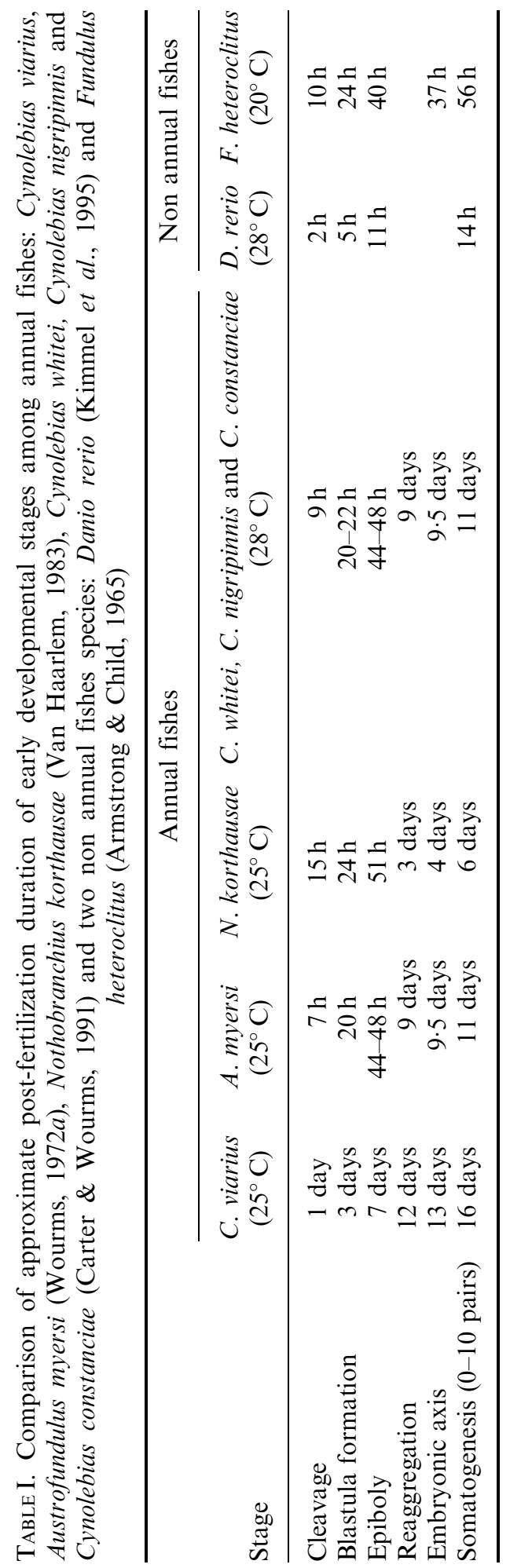



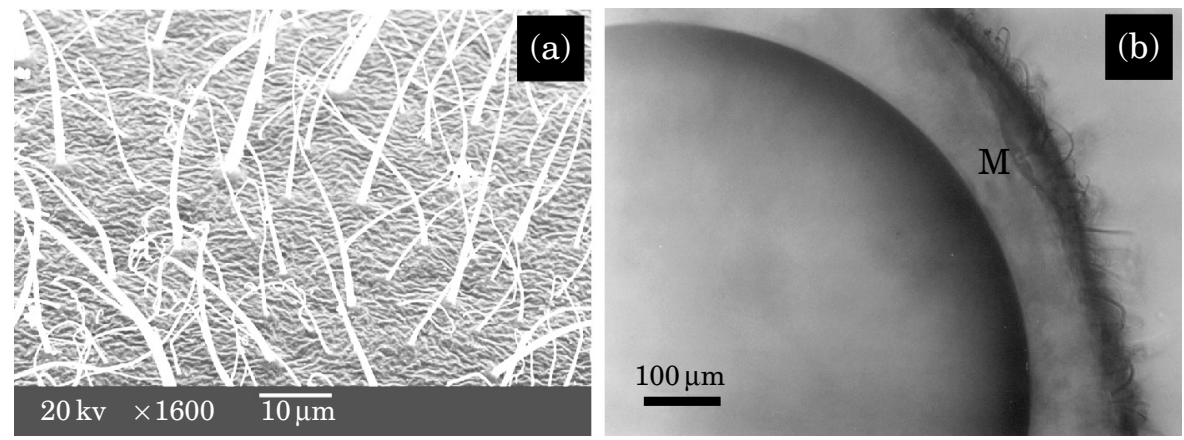

FIG. 2. Some features of Cynolebias viarius oocytes: (a) chorion surface (SEM) and (b) animal pole of oocyte (light microscopy). M, micropyle.

several lipid droplets. The amount and size of the droplets varies among individual eggs.

One cell stage

After fertilization, a perivitelline space develops between the chorion and the cell surface of the zygote. At this stage, an accumulation of cytoplasm in the animal pole is observed. The blastodisc is easily distinguishable from the yolk mass. The process of amphimixis is shown in Figs 3(a) and 4(a).

Two cell stage [Fig. 3(b)]

The first mitotic division is meridional and divides the blastodisc into two cells of equal size. There is no cell membrane between the cytoplasm of the blastomeres and the yolk cytoplasmic layer.

\section{Four and eight cell stage}

The planes of the second and third cleavages are also meridional. Eight blastomeres of approximately equal size are generated and all of them are in contact with the yolk.

\section{Sixteen cell stage [Fig. 3(c)]}

At this stage, the animal pole consists of a solid cluster of cells. There are one or two centrally located blastomeres that are completely surrounded by the others.

\section{Thirty-two - 64 cell stage [Fig. 3(d)]}

The hemispherical blastoderm consists of two kinds of cells: an outer layer of peripheral blastomeres that gradually flatten and a population of rounded and centrally-located blastomeres called deep cells. Cleavage becomes asynchronous at this stage.

\section{Blastula formation}

Several transitional stages are recognized as the blastoderm becomes hollow and flat [Figs 3(e), (f) and 4(b), (c)]. First, the blastoderm expands along and over the yolk mass while a cavity (segmentation cavity or blastocoel) forms in 

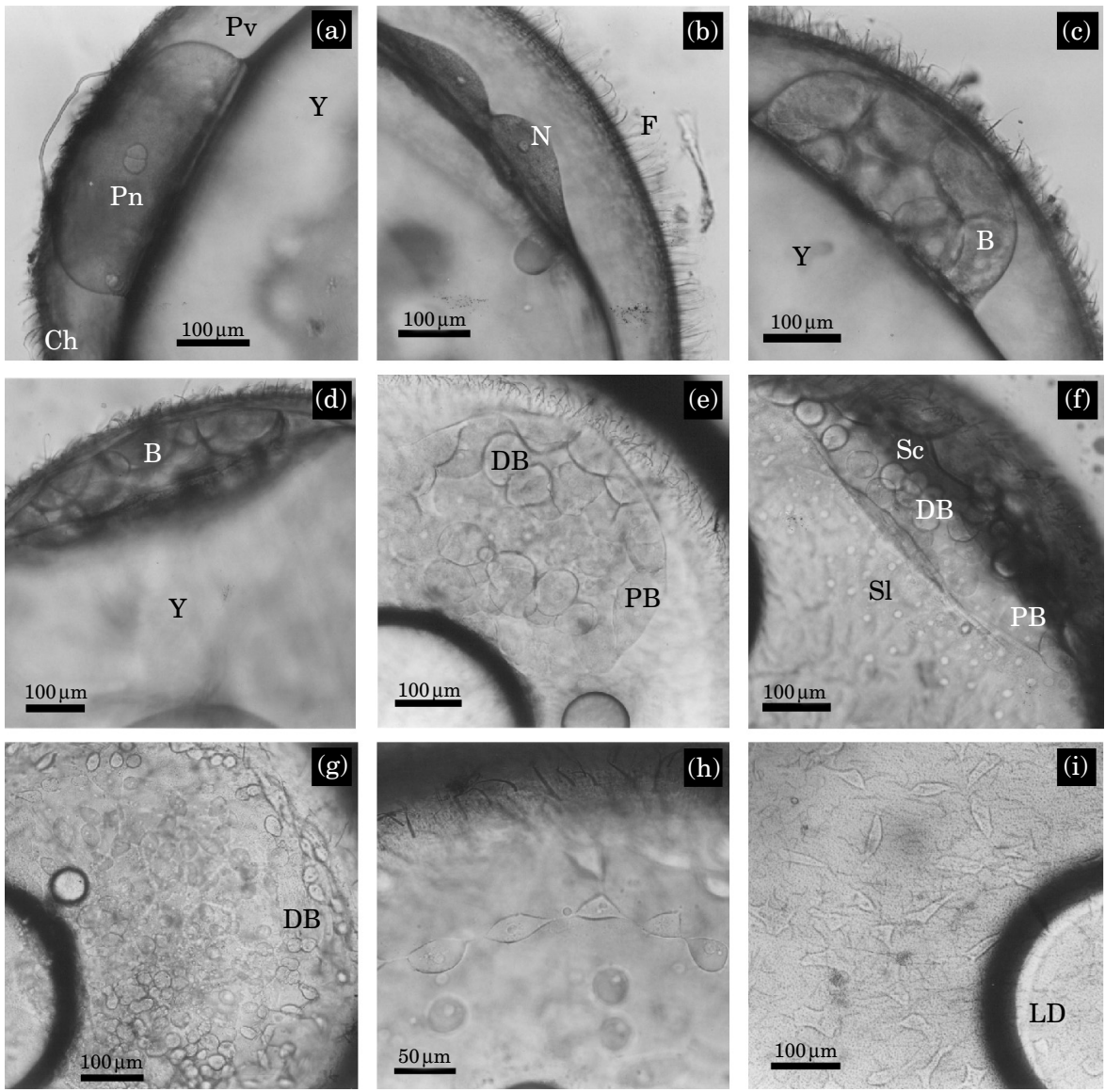

FIG. 3. Development of Cynolebias viarius embryo from fertilization to dispersion stage: (a) one cell stage embryo (amphimixis process) (Ch, chorion; Pn, pronucleus; Pv, perivitelline space; Y, yolk), (b) two cell stage (F, chorion fibrils; N, nucleus), (c) 16 cell stage (B, blastomere; Y, yolk), (d) 32-64 cell stage (time post-fertilization: 1 day) (B, blastomere; Y, yolk), (e) early blastula (DB, deep blastomere; PB, peripheral blastomere), (f) late blastula (time post-fertilization: 3 days) (DB, deep blastomere; PB, peripheral blastomere; Sc, segmentation cavity; Sl, syncitial layer), (g) epiboly (DB, deep blastomere), (h) deep blastomeres in active dispersal, arranged in short rows with fine cytoplasmic extensions and (i) dispersed phase (time post-fertilization: 7 days) (LD, lipid droplet).

its centre. The outer blastomeres form the enveloping cell layer. Initially, they are mononucleated, then they become binucleate and finally multinucleate. The segmentation cavity is 'roofed' by the enveloping cell layer. Within the cavity the spherical blastomeres (deep cells) are loosely arranged and centrally located. The cell population increases in number and the blastoderm continues to flatten. At the edge of the expanding blastoderm small nuclei organized in rows appear in the yolk syncitial layer.

\section{Epiboly}

The blastoderm expands over the yolk mass towards the vegetal pole [Figs 3(g) and 4(d)]. The nuclei of the enveloping cell layer are located at the 

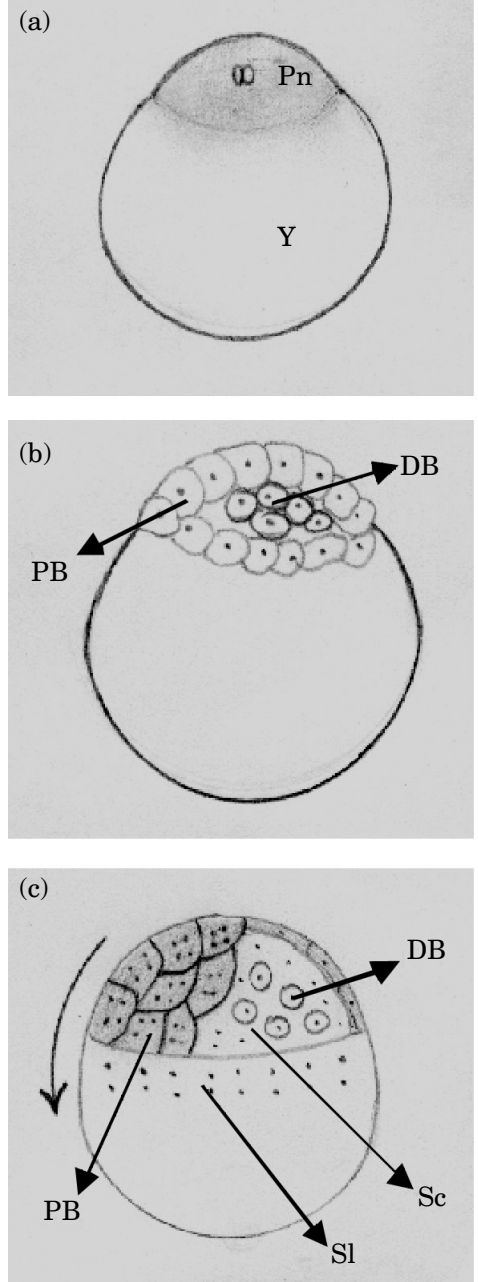

(d)

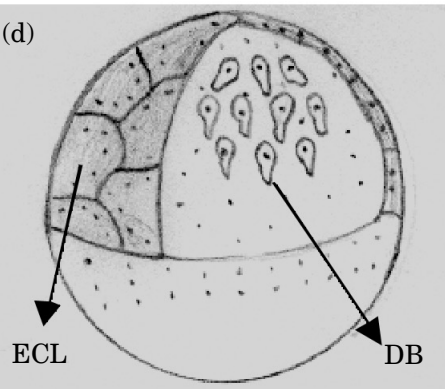

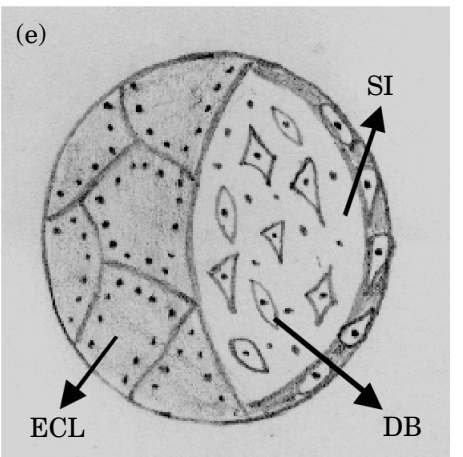
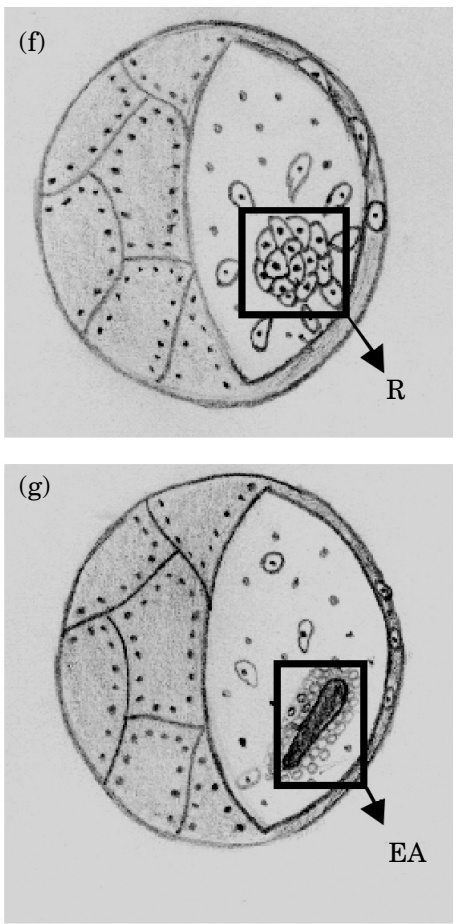

FIG. 4. Schematic representation of main developmental stages in Cynolebias viarius: (a) one cell stage (Pn, pronucleus; Y, yolk), (b) early blastula (DB, deep blastomere; PB, peripheral blastomere), (c) late blastula (DB, deep blastomere; PB, peripheral blastomere; Sc, segmentation cavity; Sl, syncitial layer; $\hookrightarrow$, movement direction), (d) epiboly (DB, deep blastomere; ECL, enveloping cell layer), (e) dispersed phase (S1, syncitial layer; DB, deep blastomere; ECL, enveloping cell layer), (f) early reagreggate (highlighted by square) ( $\mathrm{R}$, reagreggate) and $(\mathrm{g})$ embryonic axis (highlighted by square). (EA, embryonic axis). 
periphery. The advancing edge of the blastoderm includes concentric rows of nuclei belonging to the yolk syncytial layer. The blastomeres inside the segmentation cavity begin to flatten and, at the same time, they migrate individually and lose contact with one another. At about one fourth epiboly, the number of these deep cells is $c$. 100 .

Migration takes place, from the animal pole, between the enveloping cell layer and the yolk syncitial layer. As they migrate, the blastomeres either contact the enveloping cell layer or the yolk syncitial layer (unpubl. obs.). During the active dispersal phase, the blastomeres are triangular, elongated or rhomboidal in shape. These cells can be seen isolated or arranged in short rows; fine cytoplasmic extensions connect the cells [Fig. 3(h)].

At the end of epiboly, the yolk mass is covered by the yolk syncytial and the enveloping cell layers. The deep blastomeres lie between these two layers and are dispersed over the egg surface.

\section{Dispersed phase}

Blastomeres are completely and apparently randomly dispersed. In some cases, they have filopodia contacting them [Figs 3(i) and 4(e)]. Elongated cells have an average length of $80 \mu \mathrm{m}$. The lipid droplets, which are fewer in number than in previous stages, appear in a peripheral position on the yolk. At this stage, the first diapause can occur but in the standardized conditions used in the present study it did not take place. Embryos maintained in peat moss inside the aquaria with adults, however, reached disperse phase and remained at this stage until transferred to Yamamoto solution.

\section{Reaggregation phase}

This stage is characterized by a region of increasing cell density (divisions proceed while cells are becoming closer) [Fig. 5(a)]. Deep cells migrate towards this zone forming a loose aggregate that is one cell thick. There is only one site of aggregation per embryo.

As development proceeds the aggregate undergoes some changes. As the area of the cluster increases, the deep cells become rounded again; their size is similar to that shown before dispersion [Figs 4(f) and 5(b)]. Finally, these cells end up tightly packed and smaller in size. First, they form a disc and then an elliptical plate several cell layers thick at its centre [Fig. 5(c)]. This condition is identifiable by simple side observation of the embryo. In all the embryos observed some dispersed cells remained outside the plate.

\section{Embryonic axis}

This transitory stage is characterized by a linear arrangement of cells that appears at the midline of the elliptic plate. Two parallel lines of cells following the major axis of the reaggregate are identifiable [Fig. $4(\mathrm{~g})]$.

\section{Neural keel (zero to three somite pairs)}

The neural keel extends along the embryonic axis. The embryo's posterior end can be identified by the presence of Kupffer's vesicle whereas the anterior end is wider. [Fig. 5(d)]. The first three pairs of somites can be seen at the mid-way along the antero-posterior axis. 

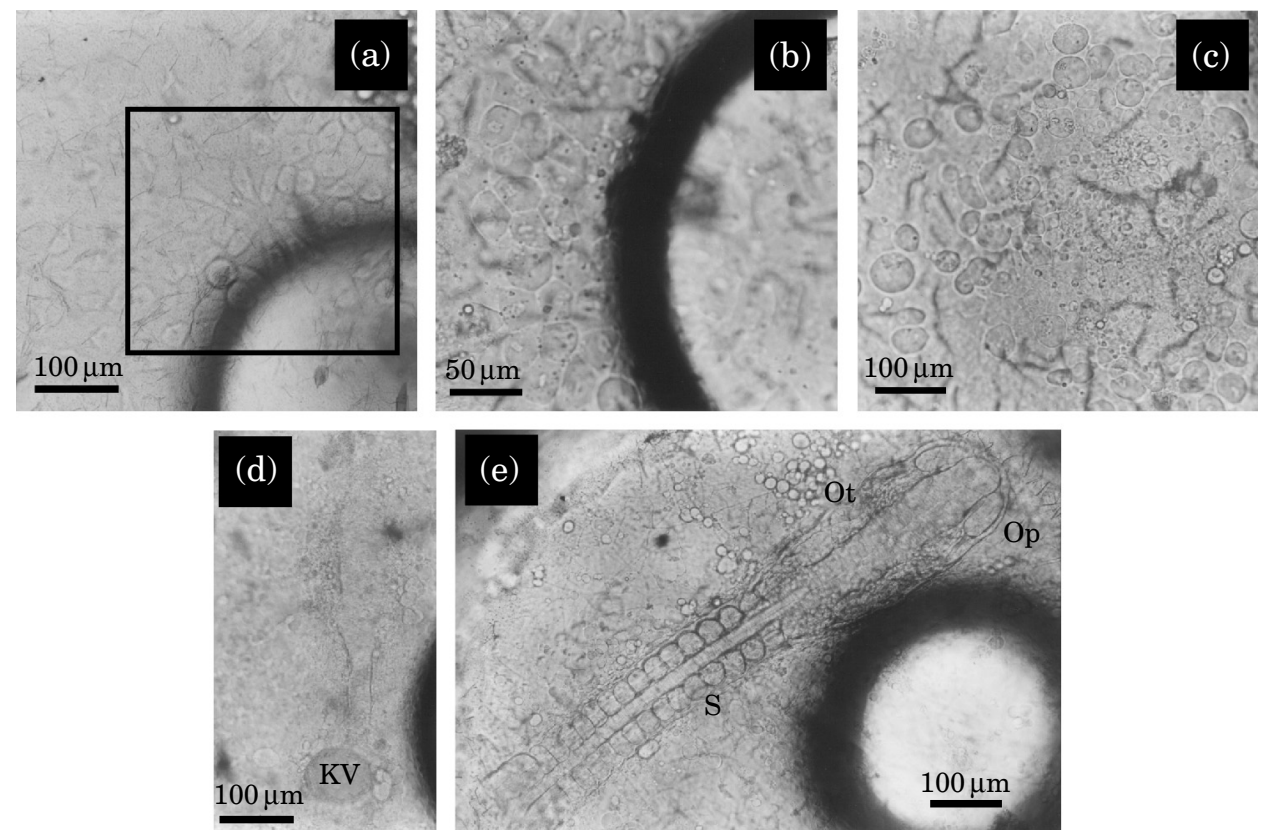

FIG. 5. Development of Cynolebias viarius embryo from reaggregation to 15 somite embryo: (a) early reagreggate (highlighted by square), (b) advanced reagreggate, (c) late reagreggate (time post-fertilization: 12 days), (d) neural keel (time post-fertilization: 13 days) (KV, Kupffer's vesicle) and (e) 15 somite embryo (time post-fertilization: 18 days) (Op, optic vesicle; Ot, otic vesicle; S, somites).

\section{Early somite embryo (three to 15 somite pairs)}

Somites form in groups of three pairs per day until the ninth pair, after which, the rate of formation increases. The cephalic region is characterized by the presence of the developing brain, optic and otic vesicles. Optic vesicles are the most anterior ones and they project laterally. Otic vesicles lacking otoliths can be identified at the level of the cephalic trunk. At this stage the embryo has no pigmentation [Fig. 5(e)].

\section{DISCUSSION}

Annual fishes share with the model zebrafish features such as oviparity, ease of maintenance in the laboratory, long periods of breeding as well as transparency of eggs and embryos. Annual fishes, however, have unique stages of dispersion-reaggregation and diapauses during development. These events make them a useful model to study cell behaviour and the effect of environmental factors on development.

\section{EMBRYO CULTURE CONDITIONS}

A great number of healthy embryos could be obtained repeatedly in the culture conditions established in the present study. Wourms (1972c) reported that diapause I is facultative for the Cynolebias genus. This is supported here because in standardized laboratory conditions the embryos of $C$. viarius did not 
exhibit this arrest. Inglima et al. (1981) showed that embryos of an other annual fish, Nothobranchius guentheri (Pfeffer), cultured in aquarium water where adults were maintained, stopped in diapause I. The same effect was observed here in embryos of $C$. viarius. It has been suggested that a hypothetical diffusible factor secreted by adults could be responsible for this developmental arrest (Inglima et al., 1981).

Temperature strongly influences the duration of development. After different culture temperatures had been tried, $25^{\circ} \mathrm{C}$ was selected for optimal embryo survival and to allow a comparison of these results with the available data on early development of Austrofundulus limnaeus Shultz (Wourms, 1972a) and Nothobranchius sp. (Van Haarlem, 1983).

\section{OOCYTE CHARACTERISTICS}

The amount and appearance of the $C$. viarius oocyte yolk is similar to that of other telolecithal demersal eggs. The pattern of fibrils found in the $C$. viarius chorion is described for the first time. Loureiro \& de Sá (1996) analysed the ultrastructural pattern (SEM) of chorion surface in 13 Cynolebias species. The hair-like filaments are similar in shape to these reported for Cynolebias adloffi Ahl. Two kinds of chorion filaments, however, were identified for C. viarius based on their thickness and regular organization while Loureiro \& de Sá (1996) reported only one type. It has been suggested for freshwater fishes in general (Johnson \& Werner, 1986), and for annual fishes in particular (Wourms \& Sheldon, 1976), that surface ornamentation of the chorion is species-specific.

\section{DEVELOPMENT}

Development can be characterized by relating the time post-fertilization to discrete embryonic stages. Teleostean embryos can be studied following this criterion even though asynchrony has been reported in zebrafish embryos belonging to one female and in vitro fertilized at the same moment (Westerfield, 2000). Timing differences are more striking in annual fishes. Variation in duration of developmental stages and hatching time among genera and species within a same genus have been reported (Wourms, 1972a; Lesseps et al., 1975; Van Haarlem, 1983). Sibling eggs can produce individuals that develop in different times (Wourms, 1972c). In addition, facultative arrest in diapauses increase asynchrony, for example $A$. limnaeus can hatch at different times ranging from 40 days to $c .320$ days post-fertilization (Wourms, 1972c).

Under the present culture conditions, $C$. viarius showed the longest early development time (16 days to reach 10 somite pairs) among the annual species studied (Wourms, 1972a; Van Haarlem, 1983; Carter \& Wourms, 1991). The analysis of the different stages through the early development showed that cleavage, blastula and epiboly are longer in $C$. viarius than the same stages when compared with Nothobranchius sp. (Van Haarlem, 1983), A. limnaeus (Wourms, 1972a) and C. constanciae and C. whitei (Carter \& Wourms, 1991).

Temperature influences development duration. In $N$. guentheri, an increase of $5^{\circ} \mathrm{C}$ in temperature resulted in a reduction of 10 days in development (Markofsky \& Matías, 1977). It is therefore necessary to take in account that 
temperature variation could explain time differences between early development in $C$. viarius (embryos cultured at $25^{\circ} \mathrm{C}$ ) and $C$. whitei, $C$. nigripinnis and C. constanciae (embryos cultured at $28^{\circ} \mathrm{C}$ ) (Carter \& Wourms, 1991). Compared to non-annual fishes, it appears that $C$. viarius early development time is almost 30 times longer than zebrafish (Kimmel et al., 1995) and seven times longer than that of Fundulus heteroclitus (L.) (Armstrong \& Child, 1965) another cyprinodontiform (Table I).

In $C$. viarius, two cellular populations were identified during cleavage at the beginning of 32-64 cells stage. Peripheral blastomeres will give rise to the enveloping cell and yolk syncitial layers, while deep cells will undergo dispersion. At the beginning of blastula formation, the enveloping cell layer and a segmentation cavity can be easily identified, as reported for all other annual fishes (Wourms 1972a, b; Van Haarlem, 1983; Carter \& Wourms, 1991). In $D$. rerio, this stage is named stereoblastula because a segmentation cavity is absent (Kimmel et al., 1995). At this stage, a second important event has been reported for $F$. heteroclitus (Trinkaus, 1992) and zebrafish embryos (Kane \& Kimmel, 1993): the mid-blastula transition (cell cycles become longer and asynchronic, zygotic genes and cell motility activation) (Kane \& Kimmel, 1993). A mid-blastula transition should occur in C. viarius but it is necessary to establish the properties that identify it.

Inspite of the great variation that fishes present as the most diverse vertebrate group, teleost gastrulation follow the basic vertebrate pattern (Ho, 1992). It involves movement of deep cells to congregate and form the embryo and at the same time epiboly of the blastoderm and yolk syncitial layer. Epiboly proceeds independently of deep cell movements and depends on expansion of the enveloping cell layer and yolk syncitial layer (Trinkaus, 1984). Annual fish embryos are unique among vertebrates because epiboly is temporally and spatially separated from organogenesis. During epiboly, deep blastomeres disperse from the blastoderm over the entire syncitial layer (Wourms, 1972a,b).

The number of deep cells varies among fish species. Non annual fishes have thousands of blastomeres at the start of epiboly, e.g. 4000 in D. rerio (Kimmel et al., 1995) and 27500 in F. heteroclitus (Armstrong \& Child, 1965). Annual fishes possess fewer cells (Nothobranchius sp. between 54 and 340 among the 10 species studied, Van Haarlem, 1983; Cynolebias sp. 250 and Austrofundulus sp. 2500, Carter \& Wourms, 1991). Cynolebias viarius has c. 100 blastomeres at early epiboly, the lowest amount reported previously for the genus.

The low number of deep cells could explain their dispersed arrangement preventing their movement as a layer but rather as individual cells (M. Allende, pers. comm.). In zebrafish epiboly, the blastomeres are loosely but closely arranged while moving over the yolk (Warga \& Kimmel, 1990). Thus, it could be possible that the disperse phase is the result of the low number of deep cells and their kinetics.

The dispersing cells in $C$. viarius are round before migration but become flat and exhibit cellular extensions as migration proceeds. Triangular, elongated and rhomboidal dispersing cells were found in a similar proportion during epiboly as reported by Carter \& Wourms (1991) for other Cynolebias. In A. limnaeus the blastomeres are amoeboid (Wourms, 1972a,b). In Nothobranchius sp. dispersing cells have a variable shape which changes from spherical to triangular and 
rhomboidal. Each species of this genus has one predominant form (Van Haarlem, 1983). In a similar way to those in Nothobranchius neumanni (Hilgendorf) (Lesseps et al., 1975) C. viarius cells often move in rows maintaining contact among each other through cytoplasmic filopodia.

Teleost gastrulation is morphologically characterized by the presence of a germ ring. It consists of two cell layers: the outermost or epiblast and the innermost or hypoblast. In D. rerio (Warga \& Kimmel, 1990) and Puntus conchonius (Hamilton) (Wood \& Timmermans, 1988) the formation of the hypoblast has been described to occur by involution. Referring to F. heteroclitus, Trinkaus $(1984,1996)$ has proposed ingression (cells delaminate from their original superficial position to a deeper place) as the responsible mechanism. In Oncorhynchus mykiss (Walbaum) however, it has been reported that neither involution nor ingression occurs (Ballard, 1966). Collazo et al. (1994) interpreted that the inability to find involution in Salmo sp. (Ballard, 1966) and $F$. heteroclitus (Trinkaus, 1984) might be due to technical limitations believing involution to be the mechanism common to all teleosts. Cynolebias viarius does not possess a germ ring as in all annual fishes. Gastrulation of deep cells seems to occur in the reaggregated cell plate since the embryo axis appears in the middle of this structure. In Cynolebias sp., as in all annual fishes studied, the mechanism by which this process takes place remains to be determined.

Cynolebias viarius showed the longest early development time among the annual fish species reported. As in all annual fishes, embryos possess an identifiable blastocoel. In early epiboly, $C$. viarius has $c$. 100 deep cells, the lowest amount reported previously for the genus. They show triangular, elongated or rhomboidal morphology during the dispersing phase. Diapause I did not occur in C. viarius embryos cultured in standardized laboratory conditions. Putative presumed germ ring and embryonic shield are not distinguishable morphologically.

The authors wish to thank M. Allende and R. de Sá for helpful suggestions during the research and correction of the manuscript, G. Speranza and L. Gutiérrez for fish maintenance, M. Haro for his assistance with the figures and both referees for helpful corrections. Financial support was provided by Facultad de Ciencias, PEDECIBA (Programa de Desarrollo de Ciencias Básicas) and CONICYT (Consejo Nacional de Investigaciones Científicas y Técnicas, Uruguay).

\section{References}

Armstrong, P. B. \& Child, J. S. (1965). Stages in the normal development of Fundulus heteroclitus. Biological Bulletin 128, 143-153.

Ballard, W. W. (1966). Origin of the hypoblast in Salmo. II. Outward movement of deep central cells. Journal of Experimental Zoology 161, 211-220.

Ballard, W. W. (1981). Morphogenetic movements and fate maps of vertebrates. American Zoologist 21, 391-399.

Carter, C. A. \& Wourms, J. P. (1990). An ultrastructural analysis of the dispersed cell phase during development of the annual fish, Cynolebias. Journal of Morphology 204, 209-225.

Carter, C. A. \& Wourms, J. P. (1991). Cell behaviour during early development in the South American annual fishes of the genus Cynolebias. Journal of Morphology 210, 247-266.

Collazo, A., Bolker, J. A. \& Keller, R. (1994). A phylogenetic perspective on teleost gastrulation. The American Naturalist 144, 133-152. 
Costa, W. J. E. M. (1995). Pearl Killifishes: the Cynolebiatinae: Systematic and Biogeography of a Neotropical Annual Fish Subfamily (Cyprinodontiformes, Rivulidae). Neptune City, NJ: TFH Publications, Inc.

Costa, W. J. E. M. (1996). Phylogenetic and biogeographic analysis of the Neotropical annual fish genus Simpsonichthys (Cyprinodontiformes: Rivulidae). Journal of Comparative Biology 1, 129-140.

Costa, W. J. E. M. (1998). Phylogeny and classification of Rivulidae revisited: origin and evolution of annualism and miniaturization in rivulid fishes. (Cyprynodontiformes: Aplocheioidei). Journal of Comparative Biology 3, 33-94.

García, G., Scvortzoff, E., Máspoli, M. C. \& Vaz-Ferreira, R. (1993). Analysis of karyotypic evolution in natural population of Cynolebias (Pisces: Cyprinodontiformes, Rivulidae) using banding techniques. Cytologia 58, 85-94.

García, G., Scvortzoff, E. \& Hernández, A. (1995). Karyotypic heterogeneity in South American annual killifishes of the Genus Cynolebias (Pisces, Cyprinodontiformes, Rivulidae). Cytología 60, 103-110.

García, G., Wlasiuk, G. \& Lessa, E. (2000). High levels of mitochondrial cytochrome b divergence in annual killifishes of the genus Cynolebias (Cyprinodontiformes, Rivulidae). Zoological Journal of the Linnean Society 129, 93-100.

García, G., Lalanne, A. I., Aguirre, G. \& Cappetta, M. (2001). Insights of chromosome evolution in annual killifish genus Cynolebias through mitochondrial phylogenetic analysis. Chromosome Research 9, 437-448.

García, G., Alvarez-Valin, F. \& Gómez, N. (2002). Mitochondrial genes: signals and noise in the phylogenetic reconstruction of the annual killifish genus Cynolebias (Cyprinodontiformes, Rivulidae). Biological Journal of the Linnean Society 76, 49-59.

Ho, R. K. (1992). Cell movements and cell fate during zebrafish gastrulation. Development (Supplement), 65-73.

Inglima, K., Perlmutter, A. \& Markofsky, J. (1981). Reversible stage-specific embryonic inhibition mediated by the presence of adults in the annual fish Nothobranchius guentheri. Journal of Experimental Zoology 215, 23-33.

Johnson, E. Z. \& Werner, R. G. (1986). Scanning electron microscopy of the chorion of selected freshwater fishes. Journal of Fish Biology 29, 257-265.

Kane, D. A. \& Kimmel, C. B. (1993). The zebrafish midblastula transition. Development 119, 447-456.

Kimmel, C. B., Ballard, W. W., Kimmel, S. R., Ullmann, B. \& Schilling, T. (1995). Stages of embryonic development of the zebrafish. Developmental Dynamic 203, 253-310.

Langeland, J. A. \& Kimmel, C. B. (1997). Fishes. In Embryology. Constructing the organism (Gilbert, S. F. \& Raunio, A. M., eds), pp. 383-407. Sunderland, MA: Sinauer Associates Inc.

Lesseps, R. J., Geurts van Kessel, A. H. M. \& Denuce, J. M. (1975). Cell patterns and cell movements during early development of an annual fish, Nothobranchius neumanni. Journal of Experimental Zoology 193, 137-146.

Long, W. L. \& Ballard, W. W. (2001). Normal embryonic stages of the Longnose Gar Lepisosteus osseus. Developmental Biology 1, 1-6.

Loureiro, M. \& de Sá, R. O. (1996). External morphology of the chorion of the annual fishes Cynolebias (Cyprinodontiformes: Rivulidae). Copeia 1996, 1016-1022.

Loureiro, M. \& de Sá, R. O. (1998). Osteological analysis of the killifish genus Cynolebias (Cyprinodontiformes: Rivulidae). Journal of Morphology 238, 245-262.

Markofsky, J. \& Matías, J. R. (1977). The effects of temperature and season collection on the onset and duration of diapause in embryos of the annual fish Nothobranchius guentheri. Journal of Experimental Zoology 202, 49-56.

Máspoli, M. C. \& García, G. (1988). Estudio comparativo del cariotipo de especies del género Cynolebias Steidachner, 1876 (Cyprinidontiformes, Rivulidae) del Uruguay. Boletín de la Sociedad Zoológica del Uruguay 2a época 4, 27-33.

Metscher, B. D. \& Ahlberg, P. E. (1999). Zebrafish in context: uses of a laboratory model in comparative studies. Developmental Biology 210, 1-14.

Myers, G. S. (1952). Annual fishes. Aquarium Journal 23, 125-141 
Trinkaus, J. P. (1984). Mechanism of Fundulus epiboly, current view. American Zoologist 24, 673-688.

Trinkaus, J. P. (1992) The midblastula transition, the YSL transition and the onset of gastrulation in Fundulus. Development (Supplement), 75-80.

Trinkaus, J. P. (1996). Ingression during early gastrulation of Fundulus. Developmental Biology 177, 356-370.

Van Haarlem, R. (1983). Early ontogeny of the annual fish genus Nothobranchius Cleavage plane orientation and epiboly. Journal of Morphology 176, 31-42.

Vaz-Ferreira, R. \& Sierra, B. (1973). Los géneros de Cyprinodontidae de aguas temporales Sudamericanas. Boletín de la Sociedad Zoológica del Uruguay 2, 36-42.

Vaz-Ferreira, R., Sierra de Soriano, B. \& Scaglia de Paulete, S. (1964). Tres especies nuevas del Genera Cynolebias Steindachner 1876 (Teleostomi, Cyprinodontidae). Comunicaciones Zoológicas del Museo de Historia Natural Montevideo 8, 1-36.

Warga, R. M. \& Kimmel, C. B. (1990). Cell movements during epiboly and gastrulation in zebrafish. Development 108, 569-580.

Westerfield, M. (2000). The Zebrafish Book. A Guide for the Laboratory Use of Zebrafish (Danio rerio), 4th edn. Eugene, OR: University of Oregon Press.

Wood, A. \& Timmermans, L. P. M. (1988). Teleost epiboly: a reassessment of deep cell movement in the germ ring. Development 102, 575-585.

Wourms, J. P. (1964). Comparative observations on the early embriology of Nothobranchius taeniopygus and Aplocheilicthys pumilis with special reference to the problem of naturally ocurring embryonic diapause in teleost fishes. Annual Report East African Freshwater Fisheries Institute 1964, 68-73.

Wourms, J. P. (1967). Annual Fishes. In Methods in Developmental Biology (Wilt, F. H. \& Wessels, N., eds), pp. 123-137. New York: Thomas and Crowell Company.

Wourms, J. P. (1972a). The developmental biology of annual fishes. I. Stages in the normal development of Austrofundulus myersi Dahl. Journal of Experimental Zoology 182, $143-168$.

Wourms, J. P. (1972b). The developmental biology of annual fishes. II. Naturally occurring dispersion and reaggregation of blastomeres during the development of annual fish eggs. Journal of Experimental Zoology 182, 169-200.

Wourms, J. P. (1972c). The developmental biology of fishes. III. Pre-embryonic diapause of variable duration in the eggs of annual fishes. Journal of Experimental Zoology 182, 389-414.

Wourms, J. P. \& Sheldon, H. (1976). Annual fish oogenesis. II. Formation of the secondary egg envelope. Developmental Biology 50, 355-366.

Yamamoto, T. (1967). Medaka. In Methods in Developmental Biology (Wilt, F. H. \& Wessels, N., eds), pp. 101-111. New York: Thomas and Crowell Company. 